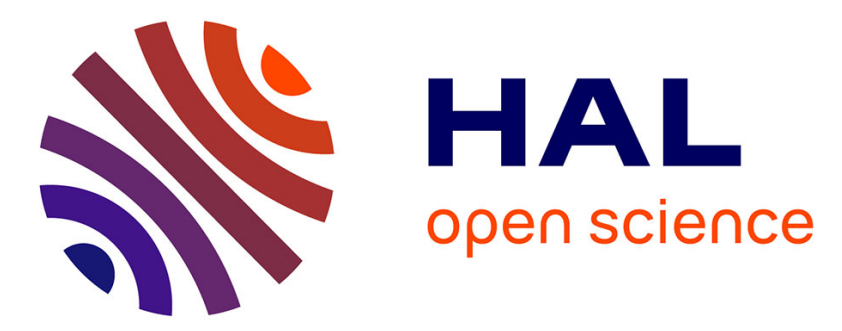

\title{
Analysis and simulation of local and regional conditions for the heavy rainfall over Lago Maggiore durint MAP IOP 2B
}

\author{
N. Ascencio, J. Stein, M. Chong, François Gheusi
}

\section{- To cite this version:}

N. Ascencio, J. Stein, M. Chong, François Gheusi. Analysis and simulation of local and regional conditions for the heavy rainfall over Lago Maggiore durint MAP IOP 2B. Quarterly Journal of the Royal Meteorological Society, 2003, 129 (588), pp.565-586. 10.1256/qj.02.37 . hal-00135844

\author{
HAL Id: hal-00135844 \\ https://hal.science/hal-00135844
}

Submitted on 17 Sep 2021

HAL is a multi-disciplinary open access archive for the deposit and dissemination of scientific research documents, whether they are published or not. The documents may come from teaching and research institutions in France or abroad, or from public or private research centers.
L'archive ouverte pluridisciplinaire HAL, est destinée au dépôt et à la diffusion de documents scientifiques de niveau recherche, publiés ou non, émanant des établissements d'enseignement et de recherche français ou étrangers, des laboratoires publics ou privés.

\section{(c)(1)}

Distributed under a Creative Commons Attribution| 4.0 International License 


\title{
Analysis and simulation of local and regional conditions for the rainfall over the Lago Maggiore Target Area during MAP IOP 2b
}

\author{
By N. ASENCIO ${ }^{1 *}$, J. STEIN ${ }^{1}$, M. CHONG ${ }^{2}$ and F. GHEUSI $I^{2,3}$ \\ ${ }^{1}$ CNRM, Météo-France, Toulouse, France \\ ${ }^{2}$ Laboratoire d'Aérologie, CNRS and Université Paul Sabatier, Toulouse, France \\ ${ }^{3}$ Climate Science, ETH Zurich, Switzerland
}

\begin{abstract}
SUMMARY
The Mesoscale Alpine Programme (MAP) operational and research network collected a large variety of measurements during the two days of Intensive Observing Period (IOP) $2 b$ (19 and 20 September 1999), which is one of the most intense rainfall episodes during the Special Observing Period over the Lago Maggiore area. The synoptic situation is a typical one of a southerly flow and associated convection over Alpine orography. Simulations with the non-hydrostatic Meso-NH model are used to describe the rainfall conditions and are successfully validated at the different scales allowed by the MAP data. The two types of pre-frontal orographically triggered convective episodes are described: (1) Sporadic and shallow convection occurs over the coastal mountains and propagates over the Po Valley. The chronology and the intensity of these convective episodes are driven by two main features: the low-level humidity anomalies and the middle-troposphere dry anomaly present over the Mediterranean Sea. (2) The Lago Maggiore orographic convection has a very long duration and is mainly controlled by both the intensity of the easterly low-level wind in the north part of the Po Valley and the upper-level clouds of the cold front. The different origins of the air masses transported by this easterly barrier wind and the associated local circulations are detailed.
\end{abstract}

Keywords: Convection Mesoscale Alpine Programme Orographic Precipitation

\section{INTRODUCTION}

The influence of orography on heavy precipitation distribution is one of the scientific objectives of the Mesoscale Alpine Programme (MAP) (Binder et al. 1996; Bougeault et al. 2001). The climatology of heavy precipitation over the Alps (Frei and Schär 1998) shows that frequencies are higher in autumn on the southern slopes of the Alps. The Lago Maggiore region features these maxima and was chosen for studying the mechanisms of persistent rain. The dense operational observation network of the different Alpine countries was complemented during the Special Observing Period (SOP) during the autumn of 1999 by research instruments: ground-based and airborne radars, supplementary radiosoundings, etc. The dataset collected during the Intensive Observing Periods (IOPs) allows the direct study of heavy rain and the validation of fine-scale research and operational models in this target area.

Previous studies of extreme events over the Alps (e.g. Vaison La Romaine, Brig, South Ticino, Piedmont) in the pre-MAP European project HEavy pRecipitation in the Alpine Region (HERA, see the overview paper by Volkert (2000)) have been limited by the absence of data at the fine scale to validate the model outputs and the proposed mechanisms. Nevertheless, the studies revealed some common characteristics of these cases. Potential vorticity (PV) streamers are often present along a north-south $(\mathrm{N}-\mathrm{S})$ axis at tropopause level (Massacand et al. 1998) and the associated upper-level flow has a strong meridional component. At the surface level, a cyclone and an associated cold front are the main features. So, moist and warm Mediterranean air is advected towards the Alps ahead of the front and in extreme cases yields strong pre-frontal and frontal convection (Buzzi and Foschini 2000; Stein 2000).

* Corresponding author: Centre National de Recherches Météorologiques, Météo-France , 42 Avenue G. Coriolis, 31057 Toulouse Cedex 1, France. e-mail: nicole.asencio@meteo.fr 
A complete and unique conceptual model is not available for this type of situation even if some important ingredients have already been underlined in previous studies: substructures in the frontal system (Buzzi et al. 1998), humidity distribution at low levels (Rotunno and Ferretti 2001), cold pools generated by previous convective systems (Sénési et al. 1996; Gheusi and Stein 2002), moist airflow regimes (Schneidereit and Schär 2000).

The purpose of the present study is to use the MAP dataset in order to validate a fine-mesh simulation and to characterize the causes of the orographic precipitation during a classic example of such dangerous situations. In this study we consider the IOP 2b event (19 and 20 September 1999) because the synoptic situation follows a classic scenario and one of the largest rainfall amounts for the whole SOP was measured in the Lago Maggiore Target Area (LMTA). The mesoscale model is described in section 2 and the validation of the simulation is discussed in section 3 for the large-scale aspects. After a description of the rainfall events over the Po Valley, their origins are detailed in section 4. A finer-scale analysis of the convection over the LMTA is done in section 5. We conclude in section 6 .

\section{NUMERICAL SET-UP}

The numerical simulations are performed with the anelastic non-hydrostatic mesoscale model Meso-NH. The details of the model dynamics can be found in Lafore et al. (1998). Only a brief summary is given below. This model allows the simulation of multi-scale atmospheric features from a few thousand kilometres to a few tens of metres. The spatial and temporal discretizations are second-order accurate and explicit. The Gal-Chen and Sommerville (1975) coordinate transformation is used to include the orography. The two-way interactive grid-nesting method (Stein et al. 2000) enables the simultaneous running of several models with the same vertical resolution but different horizontal resolutions. The lateral boundary conditions are given by large-scale operational analyses for the outermost model, and they are provided at every time step by the outer model for the inner model.

For resolutions greater than $3 \mathrm{~km}$, the subgrid-scale convection is parametrized by a mass-flux convection scheme (Bechtold et al. 2001). For finer grids, the convection is explicitly resolved and the convection scheme is switched off. The microphysical scheme includes the three water phases with five species of condensed water (Pinty and Jabouille 1998). The turbulence parametrization is based on a 1.5-order closure (Cuxart et al. 2000). The mixing length is computed according to the method of Bougeault and Lacarrère (1989) and only the vertical mixing is considered here. The surface scheme is the Interactions between the Soil Biosphere and Atmosphere (ISBA) scheme (Noilhan and Planton 1989) and the radiation scheme is described in Morcrette (1991). Trajectories are derived from three Eulerian passive tracers (Gheusi and Stein 2002) and give physical and dynamical information about the resolved phenomena.

In order to simulate the synoptic features over the Alpine region and the detailed fine-scale structure of the convective cells, we use two nested models for the experiment. The different horizontal resolutions are $10 \mathrm{~km}(200$ points $\times 160$ points $)$ and $2.5 \mathrm{~km}$ (200 points $\times 200$ points). The two simulation domains are shown in Fig. 1 .

The inner model includes the Rhine Valley in order to study the föhn event in the first part of IOP 2b (see Jaubert and Stein 2003), the Ligurian Apennines and the Ligurian Alps which play a major role during the pre-frontal period. The vertical grid (42 points) is stretched from $60 \mathrm{~m}$ at the ground to $800 \mathrm{~m}$ in the stratosphere, the top of the model is at an altitude of $18 \mathrm{~km}$. The simulation starts at $0000 \mathrm{UTC}$ on 19 September 


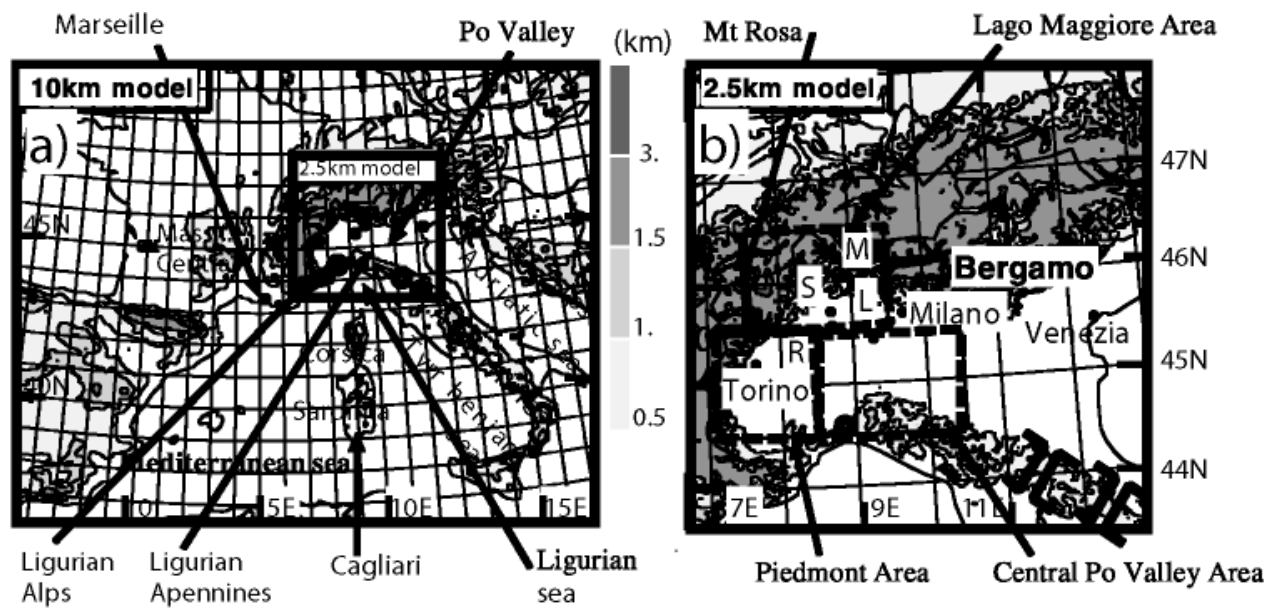

Figure 1. Nested-model domains and topographic maps with geographical references. The grey scale shows the orography, the heavy brackets mark gaps in the orography. (a) The solid-line rectangle represents the $2.5 \mathrm{~km}$ mesh model domain. (b) Inside the $2.5 \mathrm{~km}$ domain, the dashed-line rectangles represent the Lago Maggiore, Piedmont and central Po Valley areas. Radars involved in the Lago Maggiore area are also indicated with the letters L (VHF Lonate), M (Monte Lema), R (Ronsard), S (S-Pol).

1999 and lasts 54 hours. The initial conditions and lateral boundary conditions linearly interpolated in time between 6-hourly analyses are given by the French operational analysis from Action de Recherche Petite Échelle et Grande Échelle (ARPEGE, Thépaut et al. 1998).

\section{IOP 2B SIMULATION}

\section{(a) Synoptic situation}

The synoptic situation is characterized by: a deep cyclone located to the west of Ireland at 0000 UTC on 19 September, and moving towards France (Fig. 2(a)) at 1200 UTC on 20 September; a powerful stationary anticyclone over Russia $\left(40^{\circ} \mathrm{E}\right)$, which extends by a ridge as far as the south of the Mediterranean Sea east of $20^{\circ} \mathrm{E}$. In north Africa, a second cyclone (located at $10^{\circ} \mathrm{E}$ in Fig. 2(a)) moves from Morocco to Tunisia during IOP $2 b$.

An active cold front is associated with the Atlantic cyclone. At 0000 UTC, it extends along an approximately north-south axis from the British Isles to Portugal. It crosses France on 19 September and reaches the Alpine orography during the night. The eastwards evolution across the Po Valley during the 20 September is slowed down by the stationary high-pressure system over eastern Europe. This is a typical synoptic situation for heavy precipitation over the Alps because the cold-front movement will intensify the west-east pressure gradient and, therefore, the low-level jet ahead of it.

The upper-level analysis shows a cut-off low associated with the deep surface cyclone over Ireland. The potential-vorticity anomaly (Fig. 2(b)) elongates in a meridional direction on 19 September, and rotates easterly and northerly during the second day. The upper-level south-west jet over Spain on the first day, takes a meridional south-north direction along $5^{\circ} \mathrm{E}$ at the beginning of the night, and the jet exit is located over the Alpine regions. The upper-level flow remains rather stationary over the Alps in a southwesterly direction ahead of the front, and then turns to a southerly direction during the second day. The surface cold front and the upper-level jet keep their south-north 

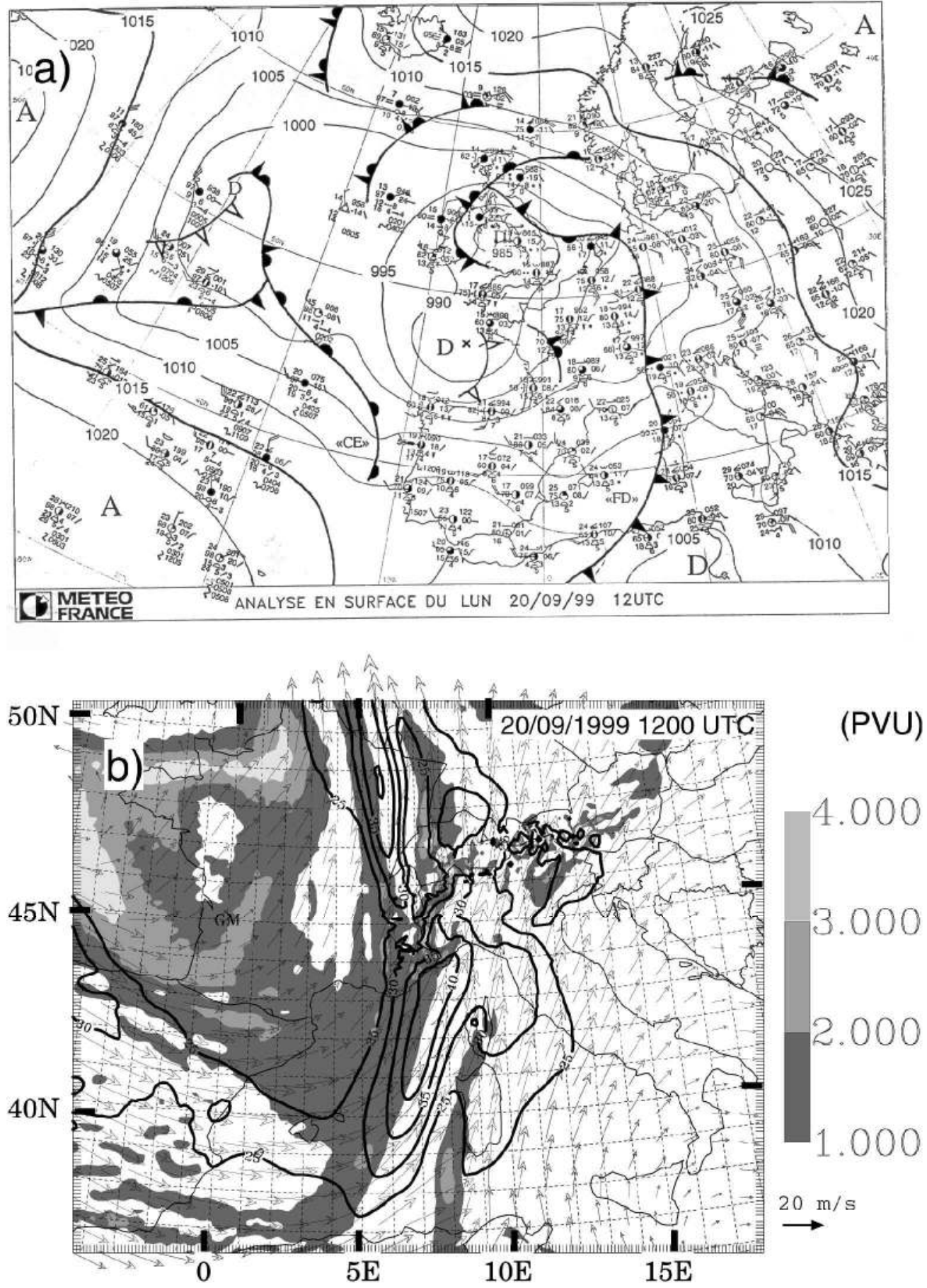

Figure 2. Météo-France analyses available at 1200 UTC on 20 September 1999. (a) Surface pressure contours (hPa) every $5 \mathrm{hPa}$ and fronts. (b) ARPEGE analysis: potential vorticity (PV units, PVU) in grey scale, intensity of the wind (thick isolines every $5 \mathrm{~m} \mathrm{~s}^{-1}$ ) greater than $25 \mathrm{~m} \mathrm{~s}^{-1}$ and wind vectors every eight grid points on the $315 \mathrm{~K}$ dry potential-temperature isosurface. 


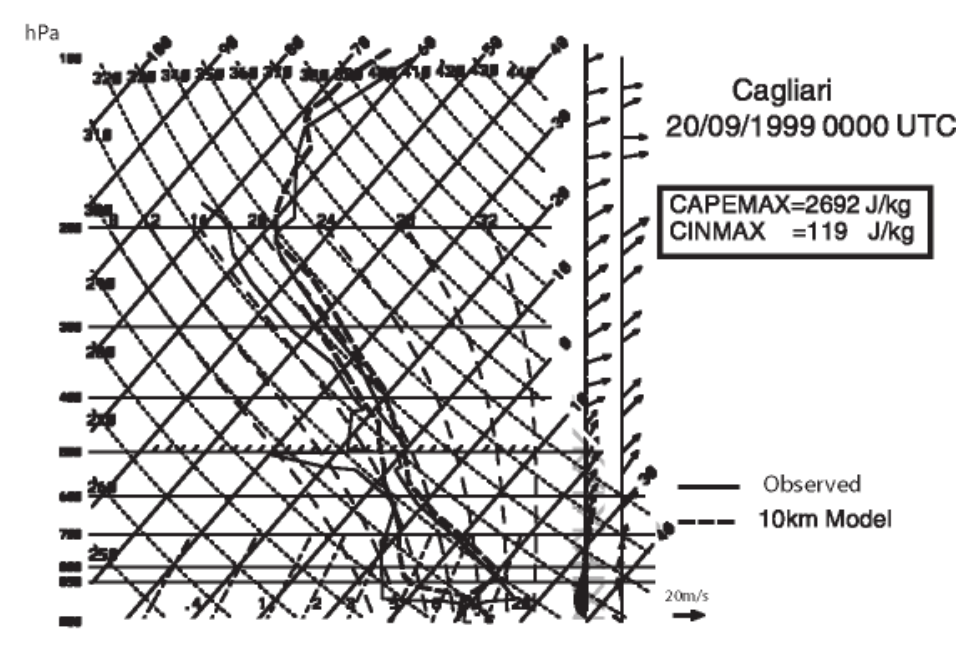

Figure 3. Observed (solid line) and simulated (dashed line) radiosounding at Cagliari (Sardinia), 0000 UTC on 20 September 1999. CAPEMAX is the maximum value of the convective available energy, CINMAX is the convective inhibition associated with the maximum CAPE.

orientation while moving eastwards across the Po Valley during the second day of the IOP.

As in the Brig, Vaison La Romaine and Piedmont cases, warm air originating from Africa crosses the Mediterranean Sea, and this leads to the formation of a conditionally unstable airmass (e.g. Sénési et al. 1996; Buzzi and Foschini 2000; Rotunno and Ferretti 2001).

The sounding launched in Sardinia samples such an air mass during this IOP (Fig. 3). The boundary-layer parcels have strong convective available potential energy (CAPE) of $2692 \mathrm{~J} \mathrm{~kg}^{-1}$, but also high convective inhibition (CIN) of $200 \mathrm{~J} \mathrm{~kg}^{-1}$ due to a low-level inversion. Strong uplift of this layer is thus needed to release the convective instability. This is only achieved when impinging on the southern European relief.

\section{(b) Mesoscale features and model validation}

Figure 4 displays the temporal evolution of wind and equivalent potential temperature at $500 \mathrm{~m}$ (above sea level) as deduced from the $10 \mathrm{~km}$ mesh model. The equivalent-potential-temperature field over the Mediterranean Sea is not homogeneous, four anomalies of enhanced values can be identified and their role will be detailed in section 4 . The front position is revealed by the sharp rotation from southerly to westerly winds: focus on the western French coasts at 0600 UTC, the western side of the French Alps at midnight and along $10^{\circ} \mathrm{E}$ at 1800 UTC. Two dominant low-level jets over the Mediterranean Sea (Figs. 4(a) and (b)) advect Mediterranean air towards the Alps before the front's arrival: a south-westerly flow associated with the cold front and a southerly flow to the south of Sardinia. These two low-level jets have a similar intensity until they merge during the morning of the 20 September (Fig. 4(c)) along $10^{\circ} \mathrm{E}$.

In order to validate the model description, we consider here some specific data collected during the IOP. We first compare the observed and simulated mean-sea-level pressure (Fig. 5) during the two days at surface stations on the southern Alpine foothills (Fig. 1 shows their location). The frontal signature is quantitatively well simulated during the two days. The quick frontal passage in Marseille can be clearly identified as the sharp pressure minimum between 2000 UTC and 2400 UTC on 19 September just 

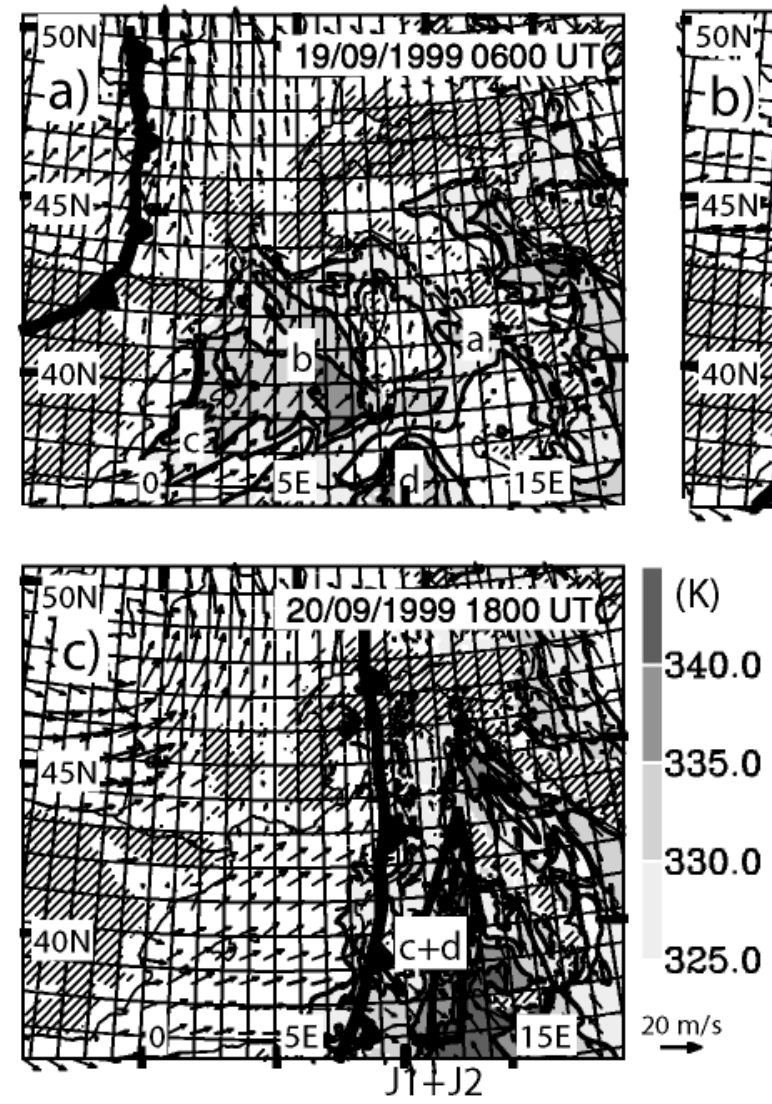

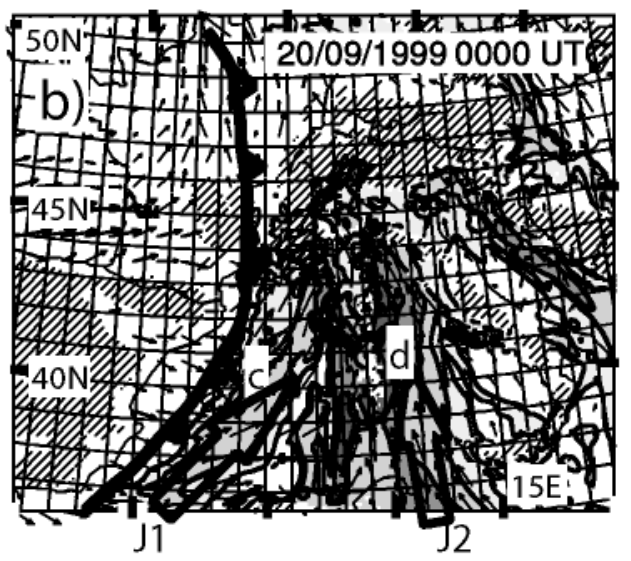

K)

40.0

35.0

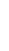

Figure 4. Equivalent potential temperature (grey scale, every $5 \mathrm{~K}$ ) and wind vectors (every four grid points) at $500 \mathrm{~m}$ above sea level, (a) at 0600 UTC on 19 September, (b) at 0000 UTC, and (c) at 1800 UTC on 20 September 1999 from the $10 \mathrm{~km}$ model. Front location, low-level humidity anomalies (named a, b, c and d) and jets (named $\mathrm{J} 1$ and $\mathrm{J} 2$ ) are also indicated.

before it reaches the foothills of the Alps. It is later observed at the Torino, Milano and Bergamo stations from 0600 UTC to 1800 UTC on 20 September as the front progresses over the Po Valley (the pressure minimum is less sharp and thus the signature of the front is less clear, however). The front slows down over the Po Valley and arrives over Venezia only late on 20 September.

The upper-level jet evolution (wind intensity and direction) associated with the PV anomaly (Figs. 2(b)) was observed by the Météo-France very high frequency (VHF) radar, deployed near Milano (marked in Fig. 1). These measurements are shown in Figs. 6(a) and (c) together with the $2.5 \mathrm{~km}$ grid results (Figs. 6(b) and (d)). In most respects, observed and simulated wind fields compare well. The south-westerly flow above $2000 \mathrm{~m}$ turns to southerly and intensifies when the frontal system arrives (Figs. 6(a) and (b)) at 0800 UTC on 20 September. However, the model overestimates the wind intensity during the morning of 20 September. In particular the simulated upperlevel jet is in excess of $12 \mathrm{~m} \mathrm{~s}^{-1}$ compared with the VHF observation. This simulated jet and associated PV anomaly (Fig. 2(b)) are $100 \mathrm{~km}$ farther east at 1200 UTC on 20 September, but their synoptic evolution from Spain to Italy is in good agreement with the operational analyses. 


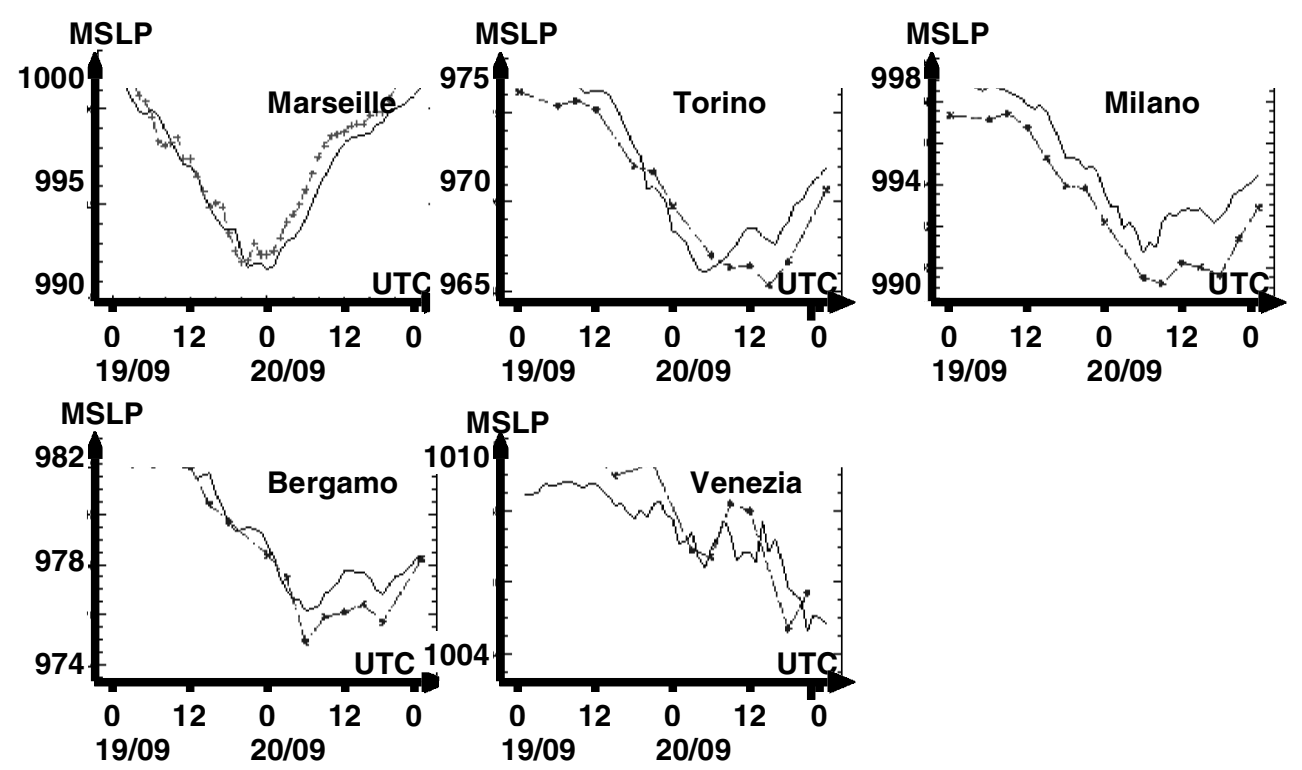

Figure 5. Mean-sea-level pressure (MSLP, hPa) on 19 and 20 September 1999 from the $10 \mathrm{~km}$ model (solid line) and surface stations (dashed line) at Marseille, Torino, Milano-Linate, Bergamo and Venezia.

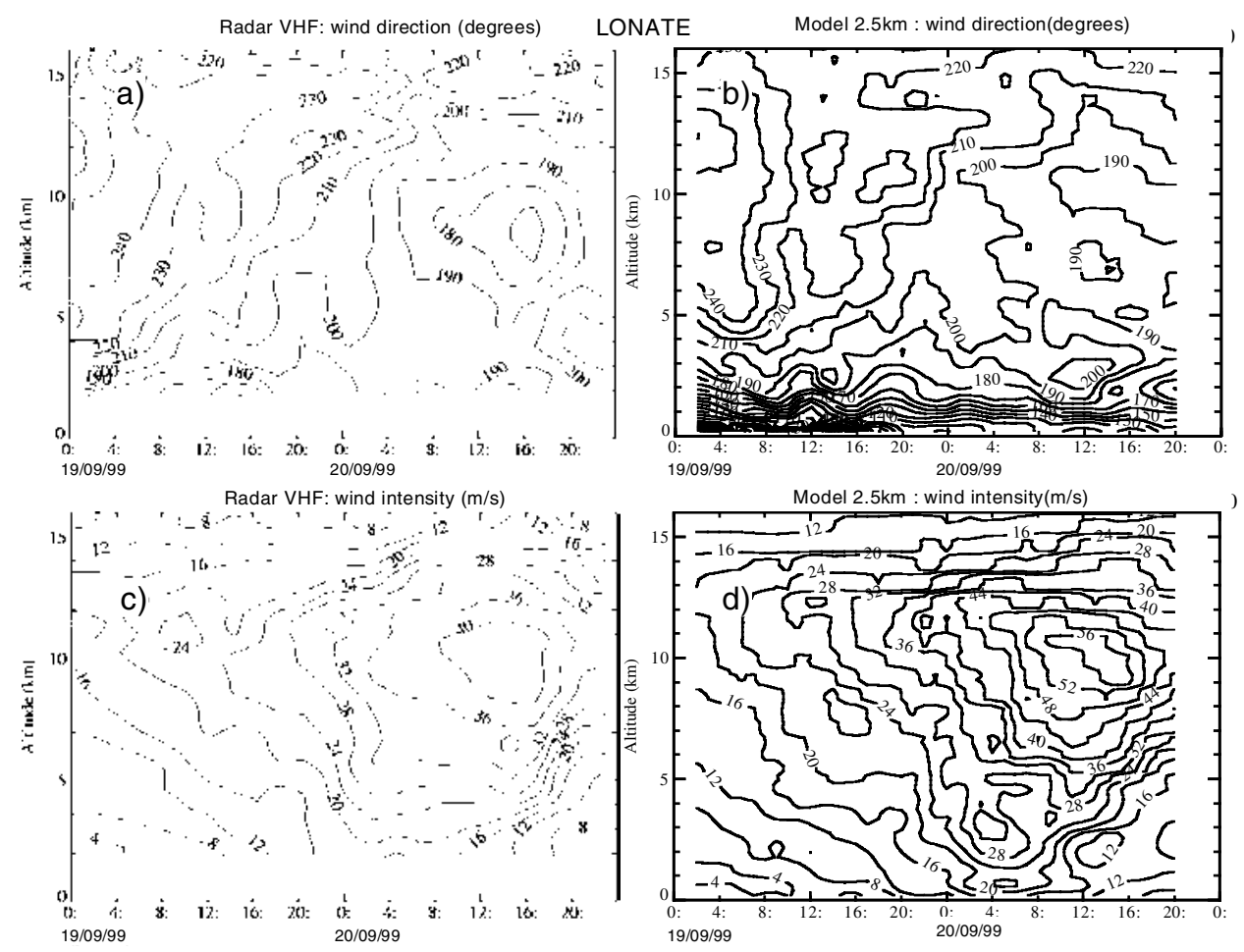

Figure 6. Time-height cross-section of (a) and (b) wind direction (degrees), and (c) and (d) wind intensity $\left(\mathrm{m} \mathrm{s}^{-1}\right)$ at Lonate, deduced from the $2.5 \mathrm{~km}$ model ((b) and (d)) and the VHF radar ((a) and (c)). 


\section{9/09/1999}
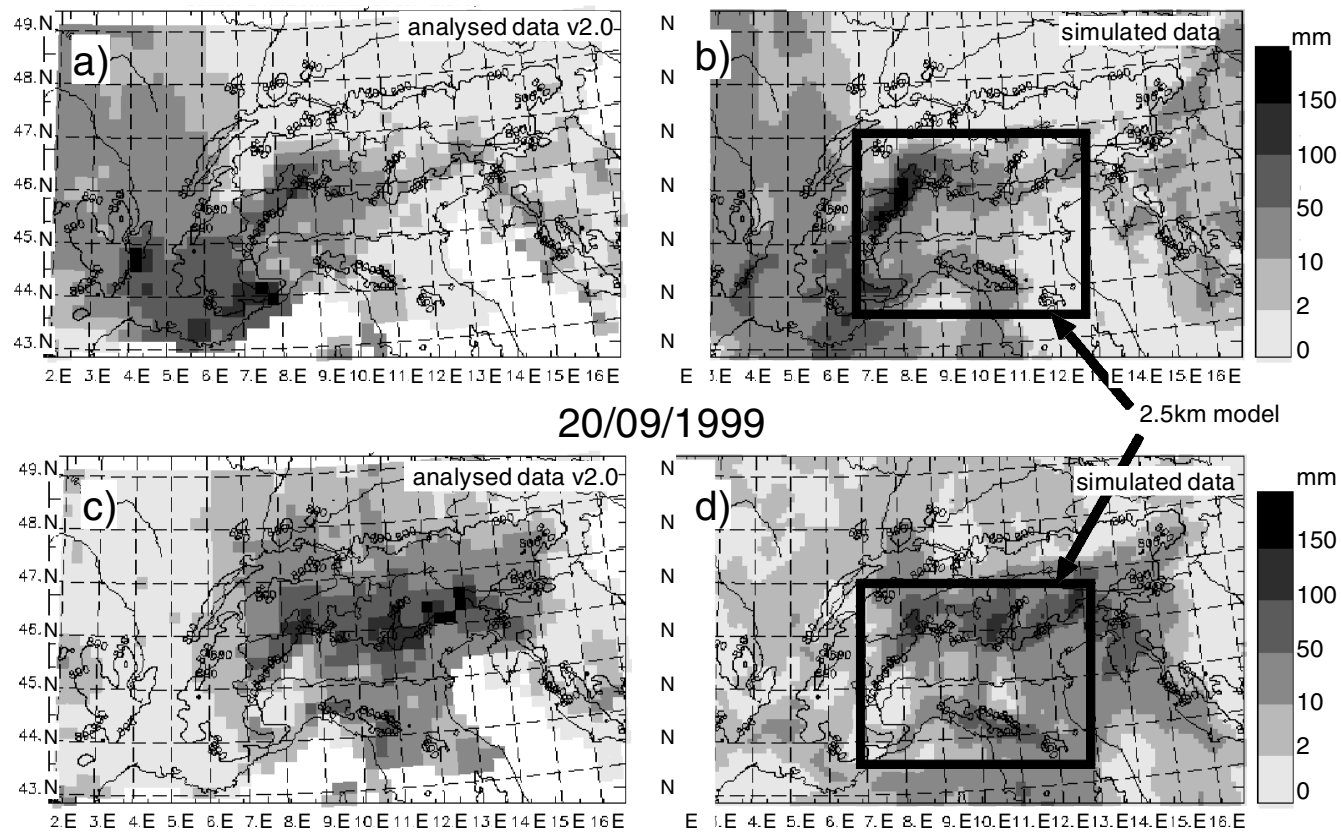

Figure 7. 24-hour accumulated rain $(\mathrm{mm})$ as deduced from (a) and (c) precipitation analysis version 2.0 by Frei and Häller (2001) averaged over $25 \mathrm{~km}$ in the horizontal, and (b) and (d) $10 \mathrm{~km}$ model averaged on a $30 \mathrm{~km}$ horizontal mesh. The rectangle represents the inner model. The labelled isoline represents the topography at $800 \mathrm{~m}$ above sea level, the other lines designate major rivers and state borders.

TABLE 1. CORRELATION COEFFICIENT BETWEEN THE 24 h ACCUMULATED RAIN ANALYSED (VERSION 2.0) BY FREI AND HÄLLER (2001) AND SIMULATED BY MESO-NH (10 km MESH)

\begin{tabular}{ccc}
\hline Day & Correlation & $\begin{array}{c}\text { Bias } \\
\text { (Model-Obs) }\end{array}$ \\
\hline 19 September 1999 & 0.75 & $+4 \%$ \\
20 September 1999 & 0.80 & $-12 \%$ \\
\hline
\end{tabular}

The comparison with these ground-based measurements validates the simulation to some extent, but the quality criterion we are most interested in is the rain distribution. The 24-hour accumulated precipitation averaged on a $30 \mathrm{~km}$ grid (a multiple of the outer grid model) from the Meso-NH simulation is compared with the precipitation analyses (version 2.0) of Frei and Häller (2001) with a horizontal resolution of $25 \mathrm{~km}$ over the whole Alpine region (Fig. 7). The spatial distribution on the southern slopes of the Alps and the temporal evolution are well recovered by the model (Figs. 7(b) and (d)). The best agreement is obtained inside the fine-mesh model domain but remains good outside it except over the Rhône Valley between the French Alps and the Massif Central. With an extension of the $2.5 \mathrm{~km}$ domain over this valley (simulation not shown), the simulated rain distribution is closer to the observations. The correlation coefficient computed with these two datasets gives an objective comparison (Table 1): the evaluation is good for the two days but the model overestimates the rainfall $(+4 \%)$ 
during the first day and underestimates it $(-12 \%)$ during the second one. Following the frontal-system progression, the accumulated rain maxima are located on the French slopes of the Maritime Alps $(170 \mathrm{~mm})$ and the Massif Central $(170 \mathrm{~mm})$ during the first day (Fig. 7(a)), then on the southern slopes of the Italian Alps (182 mm) during the second day (Fig. 7(c)). The duration of the rain accumulation (24 hours) does not allow a distinction between pre-frontal and frontal rain, but the LMTA is the only region in the Alps where significant rainfall is found on both days $(102 \mathrm{~mm}$ and $139 \mathrm{~mm}$, respectively, observed around $8.7^{\circ} \mathrm{E}, 46.1^{\circ} \mathrm{N}$ ), showing the importance of the rain mechanisms not directly linked to the cold front. In the eastern part of the Ligurian Sea $\left(10^{\circ} \mathrm{E}\right.$ in Figs. 7 (b) and (d)), a large band of precipitation associated with the northwards propagation of convective structures is simulated ahead of the frontal system.

\section{RAINFALL EPISODE OVER NORTH-WEST ITALY}

\section{(a) Description of the precipitation}

We now downscale to the Po Valley in order to have a closer look at the orographically triggered convection which is present over all the surrounding mountains. At this scale, a specific difficulty appears, linked to the higher variability of the rainfall field. The available rain-gauge measurements are less numerous and less representative in mountainous areas. This becomes critical for convective situations which imply intermittent and small-scale rain distributions as shown by the rain radars. The RAIN product of the Monte Lema radar, which is the precipitation estimated at ground level averaged over 30 minutes (Germann and Joss 2000), estimates the surface rainfall from the radar reflectivities over the western side of the Po Valley. It offers a more continuous and representative coverage in space and time, and is more suitable for validating the model at the small scale. The 6-hour accumulated rain gives a good synthesis of the observed precipitation chronology at this scale.

In order to compare the observed and simulated spatial distributions, Fig. 8 retains three periods: pre-frontal (Fig. 8(a)), frontal (Fig. 8(b)) and post-frontal (Fig. 8(c)). The pre-frontal period lasts from 0000 UTC 19 September to 0600 UTC 20 September. During this period, the cold front crosses Spain and then France (Figs. 4(a) and (b)). Over the Po Valley, the model rainfall underestimation comes from the reduction in the model of the convection intensity when the cells move downstream from the French Alps probably due to the föhn effect. Over the LMTA, both observed and simulated $6 \mathrm{~h}$ accumulated rain distributions have similar peak intensities. This is due to quasi-stationary rainfall associated with the specific type of convection described later in section 5(a). The frontal period (Fig. 8(b)) is associated with the end of the rain over the Piedmont, the intensification over the LMTA, and the generalization of rainfall over the central Po Valley. Both model and radar give the same range of intensity over the domain covered by the radar. The post-frontal period (Fig. 8(c)) during the last part of 20 September is characterized by residual orographic precipitation behind the front, over the LMTA, while the frontal precipitation moves from Bergamo to Venezia. The good simulation of the frontal passage shown in Fig. 5 is thus confirmed by the correct timing of frontal precipitation.

The correlation coefficients computed between the RAIN data and the $2.5 \mathrm{~km}$ model for the 6-hour accumulated rain (Table 2) range from 0.22 to 0.5 during the two days, with the largest value during the frontal passage over the considered domain. This comparison indicates less agreement than for the 24-hour accumulated rain (Table 1). To analyse this discrepancy, we divide the western side of the Po Valley into three areas represented in Fig. 1(b). The temporal evolution of rain averaged over each area 

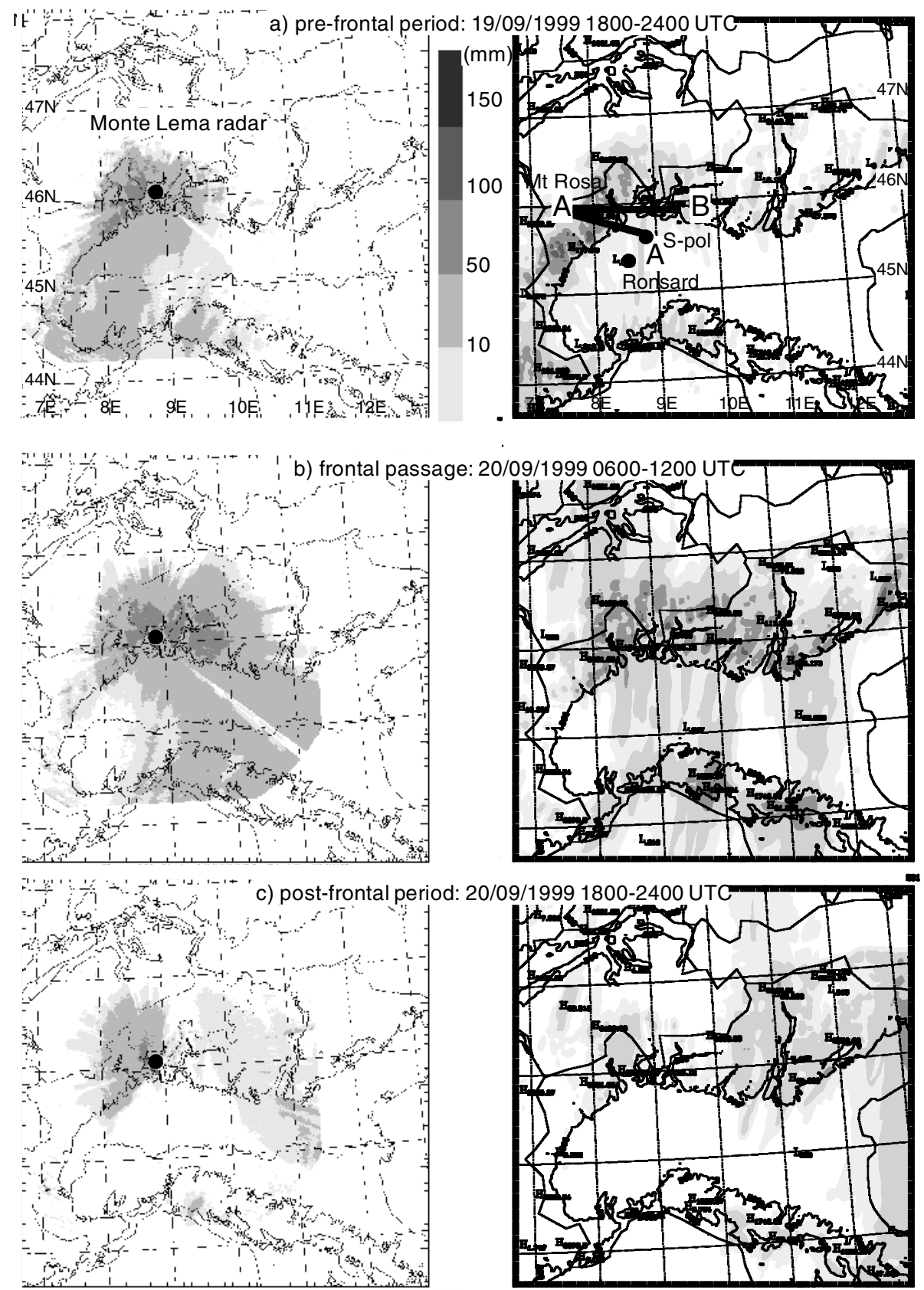

Figure 8. 6-hour accumulated rain ( $\mathrm{mm}$ ) during (a) the pre-frontal period, (b) the frontal passage, and (c) the post-frontal period, from Monte Lema radar (left panels) and $2.5 \mathrm{~km}$ model (right panels). Solid lines AA and AB indicate the positions of the vertical cross-sections shown in Figs. 12 and 13, respectively. 
TABLE 2. CORRELATION COEFFICIENT BETWEEN 6-HOUR ACCUMULATED GROUND PRECIPITATION FROM THE MONTE LEMA RADAR AND THE $2.5 \mathrm{~km}$ MODEL

\begin{tabular}{cccc}
\hline Day & Time period & Correlation & Bias (Model-obs) \\
\hline 19 September 1999 & $0600-1200$ UTC & 0.42 & $-12 \%$ \\
19 September 1999 & $1200-1800$ UTC & 0.30 & $-36 \%$ \\
19 September 1999 & $1800-0000$ UTC & 0.37 & $+5 \%$ \\
20 September 1999 & $0000-0600$ UTC & 0.41 & $+33 \%$ \\
20 September 1999 & $0600-1200$ UTC & 0.50 & $+33 \%$ \\
20 September 1999 & $1200-1800$ UTC & 0.22 & $-42 \%$ \\
20 September 1999 & $1800-0000$ UTC & 0.28 & $+31 \%$ \\
\hline
\end{tabular}

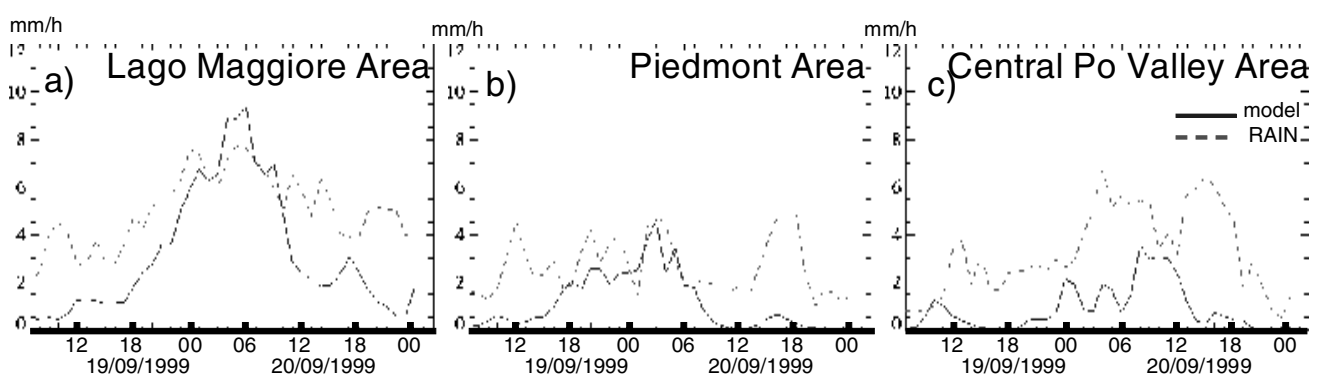

Figure 9. Temporal evolution of the hourly precipitation over the three areas located in Fig. 1(b): $2.5 \mathrm{~km} \mathrm{model}$ (solid line) and the RAIN estimation (see text) (dashed line).

(Fig. 9) shows that the $2.5 \mathrm{~km}$ model is close to the radar observations over the Alpine slopes (LMTA area) but underestimates the precipitation with a temporal shift in the two other areas where the duration of rainfall episodes is more variable. This variability is due to the convective aspect of the situation confirmed by different observations. The 24-hour accumulated rain (Fig. 7) shows an amount ranging from 10 to $50 \mathrm{~mm} \mathrm{~h}^{-1}$ over the flat Po Valley ahead of the front on 19 September. This precipitation distribution along $8^{\circ} \mathrm{E}$ in Fig. 8(a) is aligned with the wind direction in the lower free atmosphere. The $10 \mathrm{~min}$ sequence of Monte Lema radar and satellite observations (available at http://www.map.ethz.ch/, October 2002) shows that cells are triggered by the coastal orography. Part of this convection then propagates over the flat Po Valley producing rain rates sometimes greater than $10 \mathrm{~mm} \mathrm{~h}^{-1}$, and is made up of small horizontal cells of less than $20 \mathrm{~km}$ in size. Thus, the amount of hourly precipitation over the flat areas (Figs. 9(b) and (c)) remains significant compared with the mountainous regions, and is due to a succession of convective cells during the whole of IOP $2 \mathrm{~b}$.

\section{(b) Origins of the episodes}

We define an episode as a regional reinforcement of the rain during a period of a few hours. For each episode, we identify the air-mass origin and we track the evolution in the Po Valley from the entry at the coastal lines up to the arrival over the Alpine slopes. The sketches in Fig. 10 summarize such an analysis.

Each rainfall episode is associated with the arrival of a high equivalent-potentialtemperature anomaly which was previously present over the Mediterranean Sea as shown in Fig. 4. At midday on 19 September, convective cells develop when the air mass (labelled ' $a$ ' in Fig. 4) impinges on the Apennines. Their vertical development is not very extended $(<4 \mathrm{~km})$. They are then transported in the south-westerly midtropospheric flow and are reduced by the mountain-wave subsidence in the lee of the 

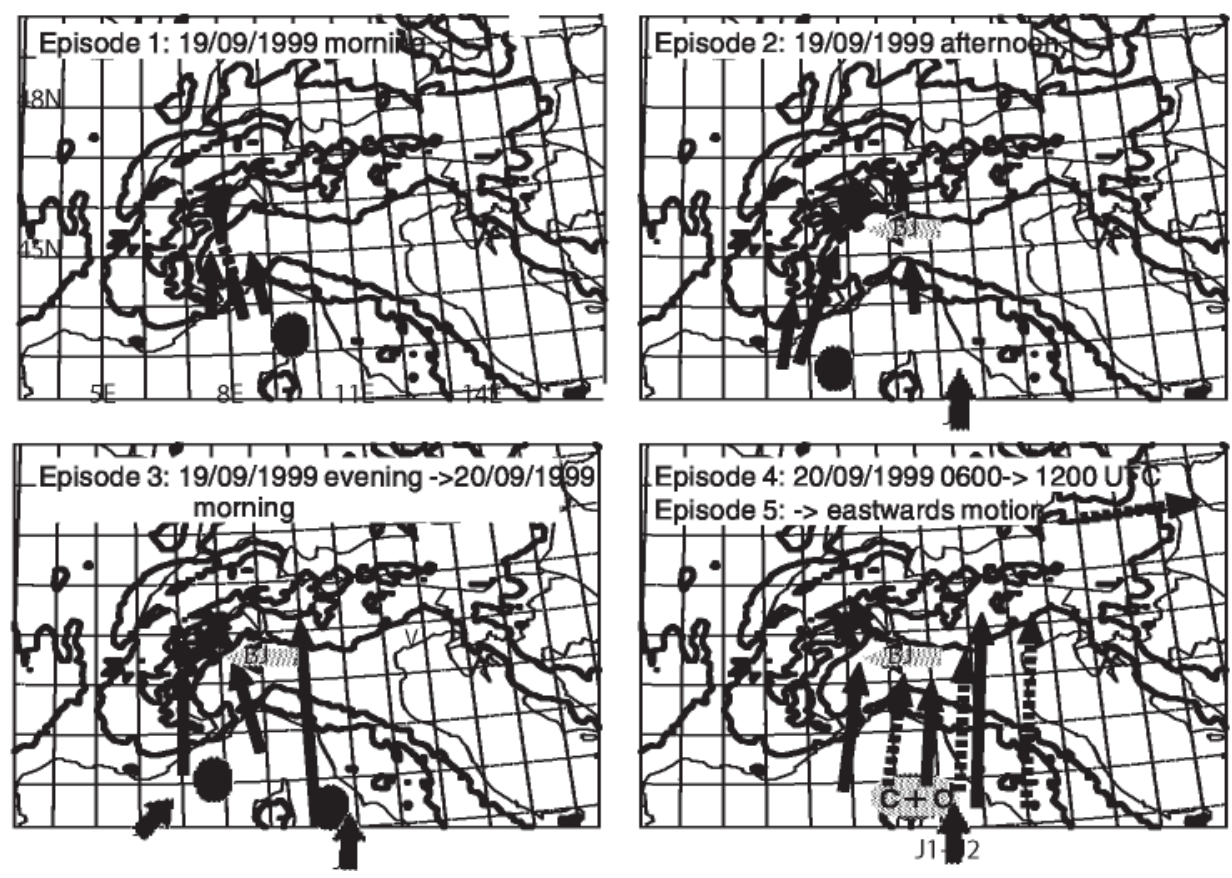

Figure 10. Chronology and scenarios of the rainfall episodes in the Po Valley during IOP 2B: (a) episode 1, midday of 19 September, (b) episode 2, on the afternoon of 19 September, (c) episode 3, night of 19/20 September, (d) episode 4, frontal arrival and episode 5, eastwards motion. The $500 \mathrm{~m}$ and $2000 \mathrm{~m}$ topographic contours are plotted as heavy lines. The black arrows show the start and the propagative motion of the cells. The grey arrows mark the low-level jets $\mathrm{J} 1$ and $\mathrm{J} 2$ over the sea, and the barrier jet (BJ), the grey letters denote the anomalies of Fig. 4.

Apennines. The rainfall is strengthened again over the Alpine slopes (episode 1 in Fig. 10) in the LMTA. During the afternoon of 19 September, the air mass labelled 'b' in Fig. 4 only gives non-propagative orographically triggered convection over the French Alps (episode 2 in Fig. 10) with a vertical development of less than $6 \mathrm{~km}$. The air mass (labelled 'c' in Fig. 4) is associated with the warm conveyor belt. East of Sardinia, the air mass (labelled 'd' in Fig. 4) documented by the Cagliari sounding (Fig. 3) progresses northwards and converges with air mass labelled 'c' over the Ligurian Sea around midnight (see Figs. 4(b) and (c)). From the evening of 19 September to the morning of 20 September, the French and Ligurian Alps as well as the Apennines trigger convective cells supplied by the two anomalies ' $c$ ' and 'd' (episode 3 in Fig. 10). During the next episode (20 September from 0600 UTC to 1200 UTC), pre-frontal and frontal precipitation occurs on both sides of the $10^{\circ} \mathrm{E}$ meridian (Fig. 8(b) and episode 4 in Fig. 10). During the post-frontal period, the merged air masses 'c $+d$ ' move eastwards together with the cold front and produce rain over the eastern Po Valley. In the postfrontal air, the cells are still triggered over the LMTA slopes (episode 5 in Fig. 10).

Provided these air-mass anomalies can be considered as precursors of the subsequent rainfall periods over the Po Valley, they are to be identified over the Mediterranean Sea. They could be determined by the initial conditions given by the operational analysis. However, the operational soundings are too sparse above the Mediterranean Sea, and the analysis is thus suspected to be of insufficient quality to provide a reliable simulation of all the episodes. In the European Centre for Medium-Range Weather Forecasts (ECMWF) analysis at 0600 UTC on 19 September (Fig. 11), the anomalies 'c' and 'd' 


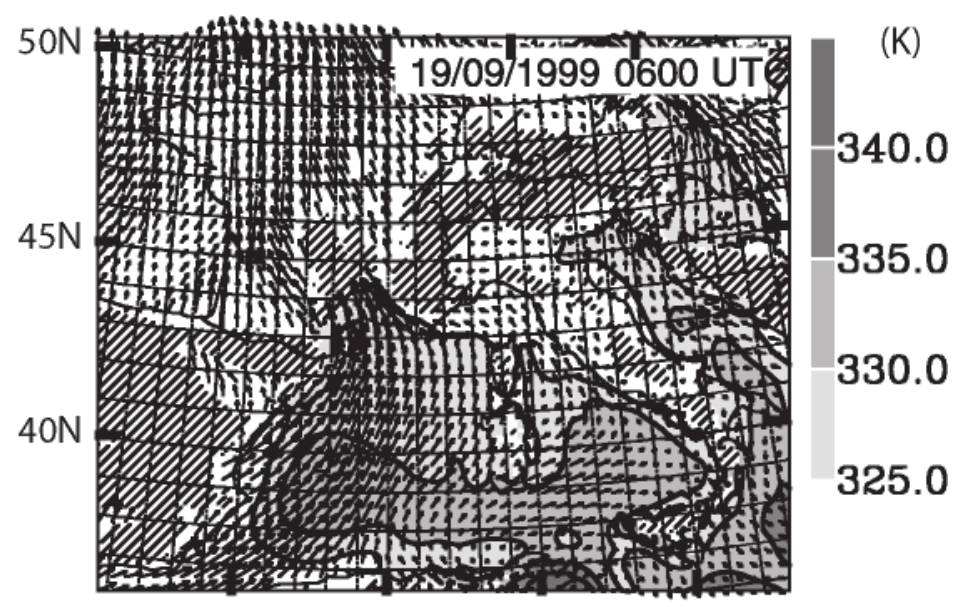

Figure 11. Equivalent potential temperature and wind vectors as in Fig. 4(a) but vectors every two grid points at 0600 UTC on 19 September 1999 as deduced from the ECMWF analysis.

do not have the same amplitude and the anomalies 'a' and ' $b$ ' do not exist at all. As a conclusion, the rain predictability over the Po Valley is strongly related to the quality of humidity analysis above the Mediterranean Sea.

\section{RAINFALL EPISODE OVER THE LMTA}

Many observations were concentrated in the LMTA and can be used to gain a more precise idea of the mesoscale circulations in this region and a detailed description of the orographic clouds.

\section{(a) Characteristics of the rainfall over the Alpine slopes}

Persistent rainfall is observed over the LMTA during the whole IOP (Fig. 7). The pre-frontal period (19 September) provides a quite similar amount of precipitation in comparison to the next two frontal and post-frontal periods. The maximum rain rate over the slopes occurs during the night (Fig. 9(a)) and the value of $10 \mathrm{~mm} \mathrm{~h}^{-1}$ is of course a mean value, local rain-gauge observations reach a very high rate of $34 \mathrm{~mm}$ in one hour.

Over the Alpine slopes, the S-Pol radar observations reveal two types of cells: some of them are formed upwind and move towards the slopes and the others are generated over the Alpine slopes and are quasi-stationary, as also found by Houze and Medina (2001). Moreover, the propagative character of part of the cells is confirmed by the delay of an average of one hour between convective features observed over the plain and over the slopes as revealed, during the pre-frontal period, by the radar network (Georgis et al. 2003 ) over the LMTA.

In order to confirm the successful representation of the rain as well as the characteristics of the convection and their evolution over the LMTA, Fig. 12 compares the reflectivity measured by the S-Pol radar (Figs. 12(a), (c), (e) and (g)) along the vertical cross-section AA (in Fig. 8(a)) from the radar up to the Monte Rosa and the reflectivity computed from the explicit precipitating hydrometeors of the $2.5 \mathrm{~km}$ model (Brandes et al. 1995). The agreement between simulation and observation is good during all the pre-frontal, frontal and post-frontal phases in terms of horizontal as well as vertical 

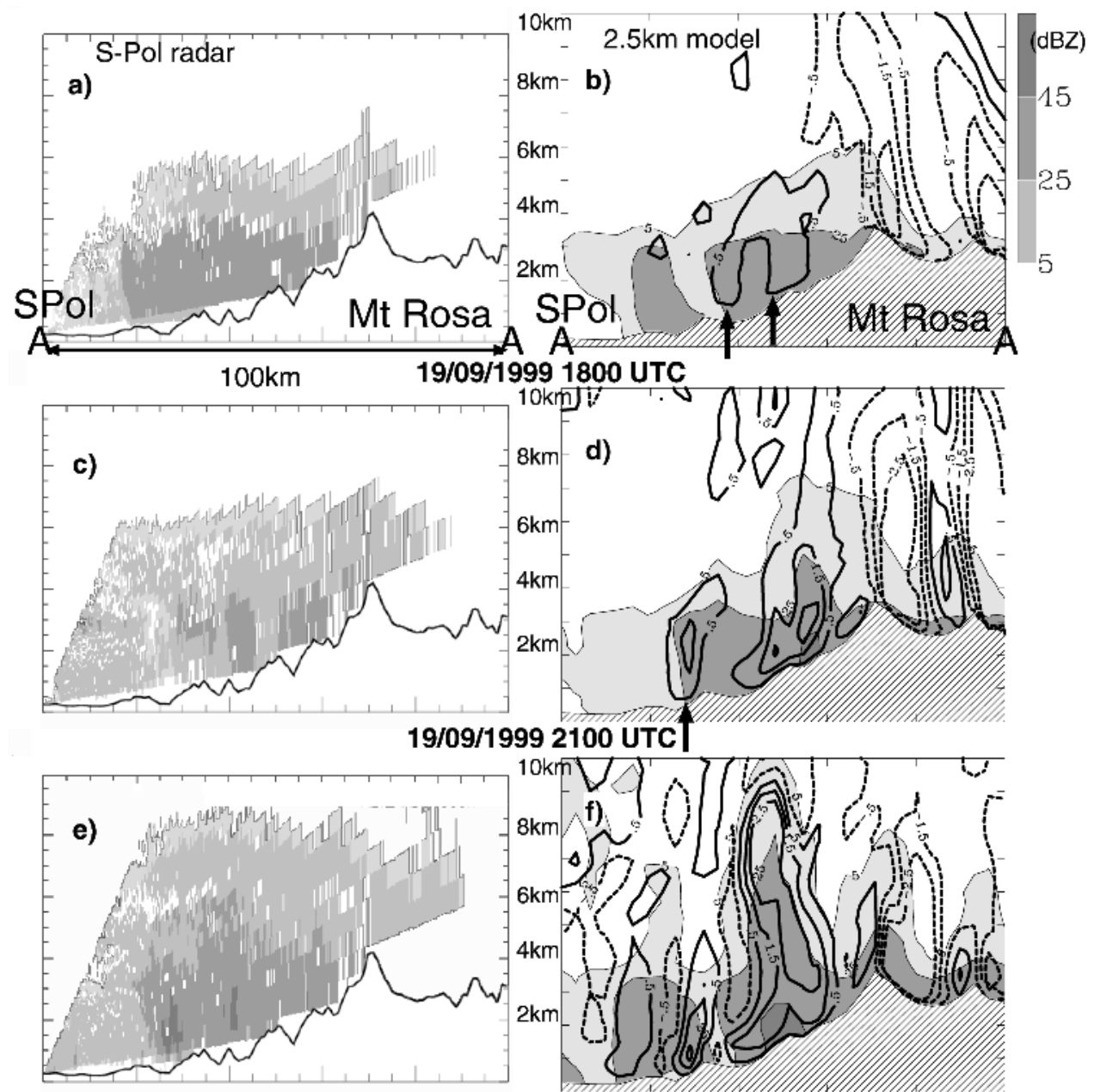

20/09/1999 0500 UTC

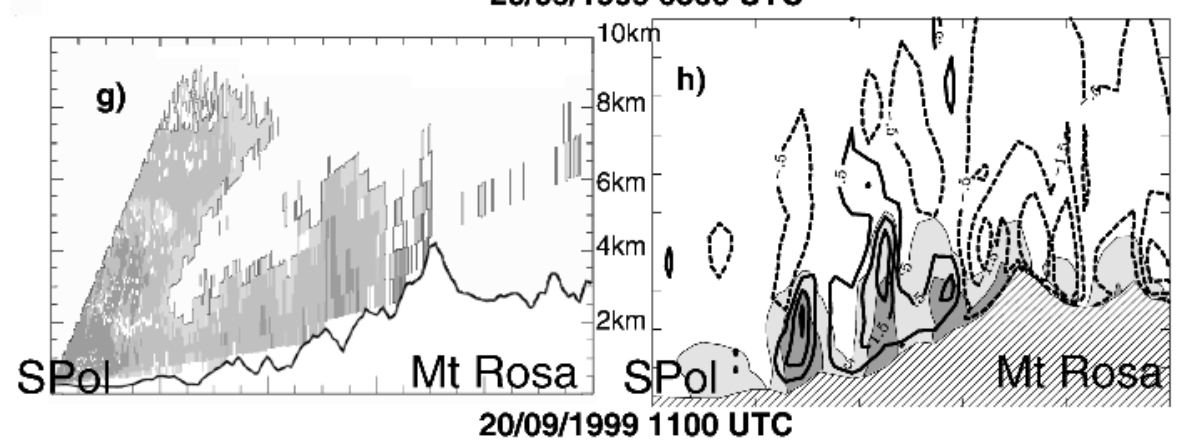

Figure 12. Vector cross-section of reflectivity (dBZ) along AA in Fig. 8(a) (S-Pol to Monte Rosa) as observed by S-Pol radar (left panels) and simulated by the $2.5 \mathrm{~km}$ model (right panels), at (a) and (b) $1800 \mathrm{UTC}$, and (c) and (d) 2100 UTC on 19 September 1999, and (e) and (f) 0500 UTC, and (g) and (h) 1100 UTC on 20 September 1999.The underlying orography is indicated. The vertical-velocity isolines $-2.5,-1.5$ and $-0.5 \mathrm{~m} \mathrm{~s}^{-1}$ (dashed) and $0.5,1.5$ and $2.5 \mathrm{~m} \mathrm{~s}^{-1}$ (solid) from the $2.5 \mathrm{~km}$ model are superimposed. The vertical arrows mark cells which are discussed in sections 5(a) and (c). 
extensions of the cells. The model fields of vertical velocity suggest the convective character of the precipitation in the region of high radar reflectivity. The vertical-velocity maxima are located at a height of $2 \mathrm{~km}$ inside the updraughts and do not follow the orography. At 1800 UTC on 19 September, some cells already present over the plain with a small vertical extent of $3 \mathrm{~km}$, reach the eastern slopes of Monte Rosa where the rainfall is enhanced by the steep slopes (small arrows in Fig. 12(b)). At 2100 UTC, the vertical velocity associated with the first slopes reaches $2.5 \mathrm{~m} \mathrm{~s}^{-1}$ and the convective rainfall intensity reaches $36 \mathrm{~mm} \mathrm{~h}^{-1}$. The front arrival at $0500 \mathrm{UTC}$ on 20 September is associated with strong vertical velocity over the valley and over the terrain as well. The vertical developments of the convective cells embedded in the frontal clouds reach $10 \mathrm{~km}$ in height. The residual post-frontal rainfall (Figs. 12(g) and (h)) is strong $\left(27 \mathrm{~mm} \mathrm{~h}^{-1}\right)$ and is still associated with cores of strong ascent but shallower convective cells (4 km deep).

The radar reveals a horizontal size of $5 \mathrm{~km}$ for the cells observed along the AA cross-section. This scale is recovered by the simulation even if it is close to the limit of resolution of the model. In summary, the rain upstream from the crest follows the same temporal evolution in the S-Pol observations and in the simulation. Behind the crest, the model shows less intense convection but is without possible confirmation by the S-Pol radar in this masked region. This is consistent with the weak rain observed during IOP 2b in Switzerland (Fig. 7).

\section{(b) Air-mass origins}

Two other Doppler radars were available in the LMTA (Monte Lema and Ronsard) and the combined use of the three radars allows the retrieval of the three-dimensional wind field according to the procedure described in Chong et al. (2000). The vertical cross-section along AB in Fig. 8(a) reveals a $2 \mathrm{~km}$ deep easterly low-level jet (Fig. 13) with a strong wind rotation above it. This low-level jet follows the orography and even passes over the Monte Rosa crest. This easterly flow, named the barrier wind, results from the westwards deviation by the combined action of the Coriolis force and the pressure gradient of the southerly incident synoptic flow slowing down when it approaches the Alpine orography (Pierrehumbert and Wyman 1985). It is rather stationary in direction as observed by the ultra high frequency (UHF) radar in Lonate (Fig. 4 in Jaubert and Stein 2003) but its intensity varies. The barrier wind impinges upon the eastern slopes of Monte Rosa, implying a strong orographic uplift of the lowlevel air there.

Figure 14 shows that this wind is strongly correlated with the rain evolution over the Lago Maggiore area (in Fig. 1(b)) during the whole IOP. Even if the upslope model (Smith et al. 2003) could give this linear correlation, the propagative cells observed by the radars and their vertical velocities given by the $2.5 \mathrm{~km}$ model suggest a more complex mechanism with a superposition of free convection already present over the plain and propagating towards the LMTA, and upslope mechanisms driven by the barrier wind and initiating new convective cells on the slopes.

To study the history of the air mass impinging on the Monte Rosa slopes, we follow two layers of this air mass located inside a $50 \mathrm{~km}$-wide square centred on the S-Pol radar at the same periods: the first layer above $2 \mathrm{~km}$ in the south-westerly flow depicted in Fig. 13 and a second layer beneath $2 \mathrm{~km}$ inside the easterly low-level jet. The backward trajectories of the upper-level layer (not shown) reveal a stationary origin from the Mediterranean and Ligurian Seas. The backward trajectories of the boundary layer (end points at $500 \mathrm{~m}$ above the S-Pol radar) in Fig. 15 describe different origins depending on the temporal evolution of the mesoscale flow around the Po Valley. At the 


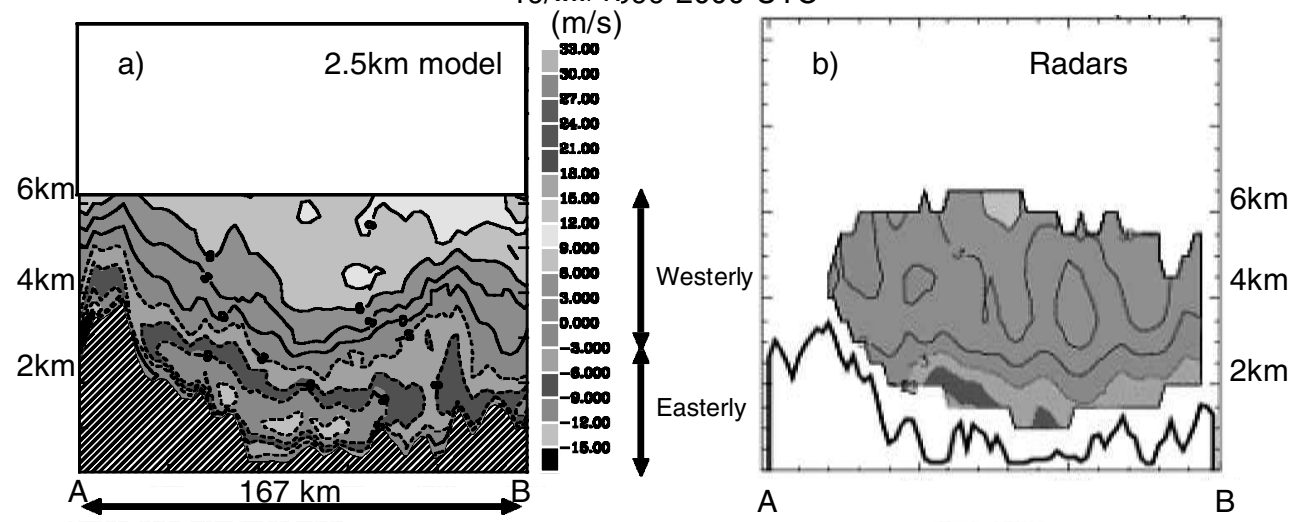

Figure 13. Vertical cross-section of the barrier wind $\left(\mathrm{m} \mathrm{s}^{-1}\right)$ along $\mathrm{AB}$ in Fig. 8(a) along with the underlying orography: (a) simulated with the $2.5 \mathrm{~km}$ model, (b) deduced from Ronsard, S-Pol and Monte Lema observations.

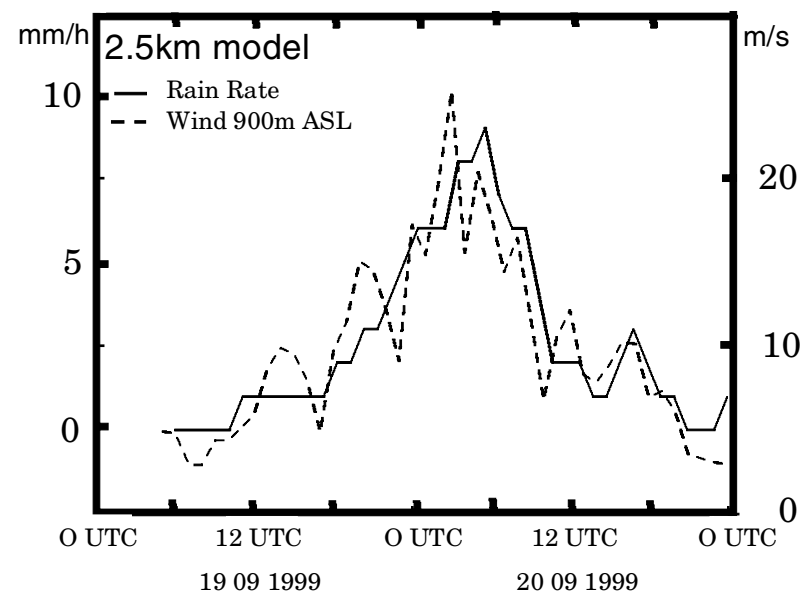

Figure 14. Temporal evolution of the intensity of the barrier wind $\left(\mathrm{m} \mathrm{s}^{-1}\right.$, dashed line) at $900 \mathrm{~m}$ above sea level (ASL), above the S-Pol location, and of the rain rate $\left(\mathrm{mm} \mathrm{h}^{-1}\right.$, solid line) over the Lago Maggiore Target Area (Fig. 1(b)) as deduced from the $2.5 \mathrm{~km}$ model on 19 and 20 September 1999.

beginning of IOP $2 b$ (1800 UTC on 19 September, Fig. 15(a)), the easterly flow is weak and the air comes from the Adriatic Sea. Then, a second source is added to it, air originating from the Ligurian Sea (2100 UTC on 19 September, Fig. 15(b)) and advected by the jet east of Sardinia, while the intensity of the easterly low-level jet increases. This second air source is displaced eastwards together with the front at 0500 UTC and 1100 UTC on 20 September (Fig. 15(c) and (d)). Later, the Adriatic source ends and the Ligurian source, advected by the southerly post-frontal flow (Fig. 15(d)), is the only one remaining. Two gaps within the Apennines, located to the south of Venezia along $11.5^{\circ} \mathrm{E}$ and $12.5^{\circ} \mathrm{E}$ and shown in Fig. 1, favour the entry into the Po Valley of air coming from the Tyrrhenian Sea. In summary, the structure of the barrier wind is complex and unsteady and it is present for a large range of the incident Mediterranean flow conditions. 

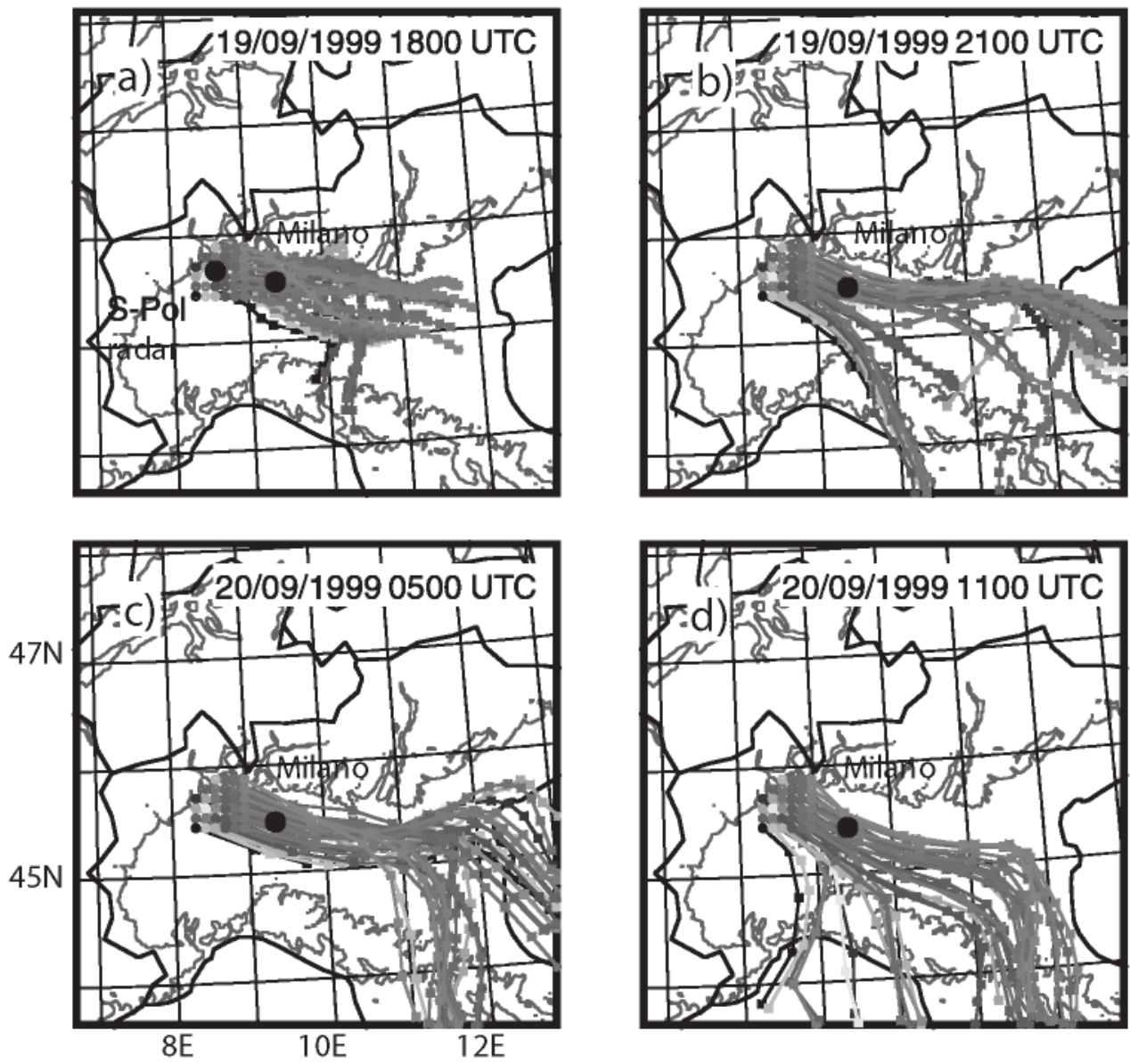

Figure 15. Backward trajectories of air ending at 500 metres above sea level in a $50 \mathrm{~km}$-wide square centred at the S-Pol location: (a) at 1800 UTC on 19 September 1999, (b) 2100 UTC, (c) 0500 UTC on 20 September 1999, and (d) 1100 UTC. The stars show the hourly locations.

\section{(c) Two types of pre-frontal convection}

Because the majority of backward trajectories in Fig. 15 coming from the LMTA pass over Milano, the thermodynamic characteristics of the incident low-level air mass over the LMTA can be analysed at Milano during the whole IOP. The CAPE values observed at Milano remain weak $\left(\simeq 300 \mathrm{~J} \mathrm{~kg}^{-1}\right)$ and steady in contrast to the rain rates over the LMTA (Fig. 14). At 2100 UTC on 19 September (Fig. 16(a)), the CAPE value simulated at Milano is similar to the observation, but very high CAPE values are present over the Ligurian Sea (ranging from 780 to $2000 \mathrm{~J} \mathrm{~kg}^{-1}$ ) associated with the humidity anomaly (labelled 'd' in Fig. 4). The vertical cross-section along CC (Fig. 16(b)), i.e. along the Ligurian entry (see Fig. 15(b)) reveals that the boundary layer in the Po Valley (between the Apennines and the Alps) is drier than the maritime one offshore from the Apennines (its mixing ratio decreases from $13 \mathrm{~g} \mathrm{~kg}^{-1}$ to $8 \mathrm{~g} \mathrm{~kg}^{-1}$ ) and is associated with smaller CAPE (Fig. 16(a)). To explain this CAPE decrease, two soundings, on either side of the Apennines and derived from the model, are shown in Figs. 16(c) and (d). The maritime boundary layer supplies the orographically triggered convection over the coastal mountain which partly consumes its CAPE (compare Figs. 16(c) and 

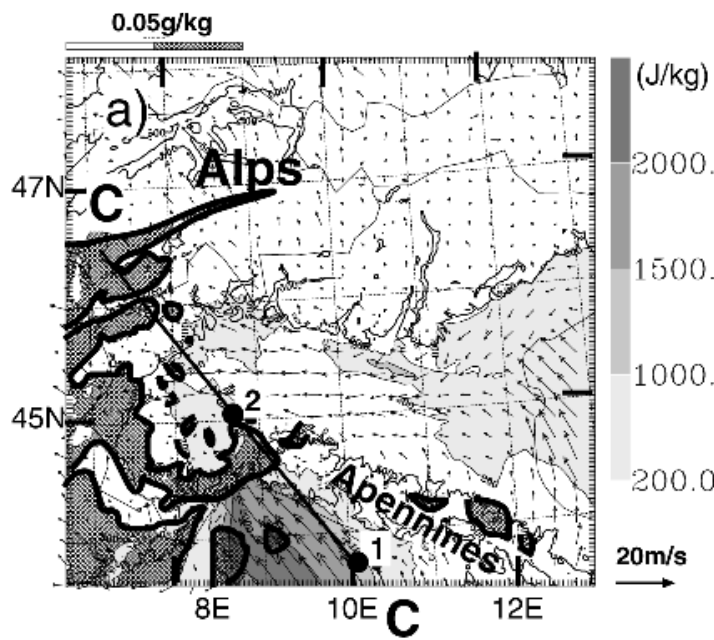

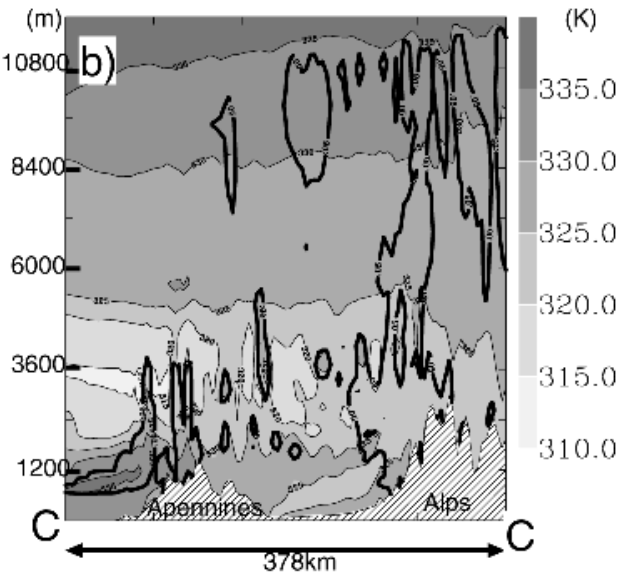

Location 1

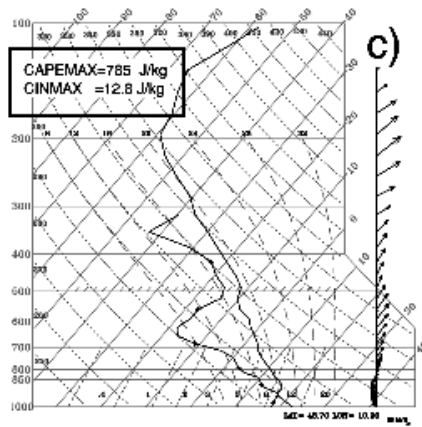

Location 2

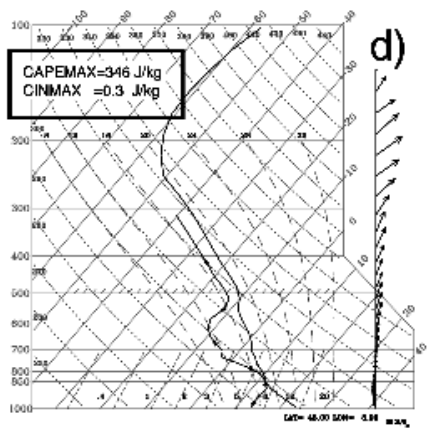

19/09/1999 2100 UTC

Figure 16. $2.5 \mathrm{~km}$ model at 2100 UTC on 19 September 1999: (a) maximum convective available potential energy (CAPE) along the vertical direction $\left(\mathrm{J} \mathrm{kg}^{-1}\right)$ in grey scale, 10-metre wind (vectors every eight grid points) and clouds ( $>0.05 \mathrm{~g} \mathrm{~kg}^{-1}$ ) at $8 \mathrm{~km}$ altitude inside heavy isolines, (b) vertical cross-section along CC of equivalent potential temperature (grey scale) and clouds (solid line), (c) and (d) soundings at two locations along the crosssection $\mathrm{CC}$, upstream from the Apennines and downstream from the Apennines. CAPEMAX is the maximum value of the convective available energy, CINMAX is the convective inhibition associated with the maximum CAPE.

(d)), with small convective developments (4 km deep). A possible explanation for the weak vertical developments is the presence of a mid-troposphere dry anomaly, seen at 3000 metres in Fig. 16(b), which inhibits the convective developments by entrainment of very dry air in the convective updraughts (Redelsperger et al. 2002). At 2100 UTC on 19 September, this dry air mass coming from north Africa (not shown), extends over the Ligurian Sea and the western Mediterranean Sea (Fig. 17) parallel to the upper-level flow, i.e. along a south-westerly oriented axis. The influence on the rain distribution of this anomaly has been studied by Gheusi and Stein (2002). All the orographically triggered convective episodes of the pre-frontal period are limited in growth over the Po Valley by this dry layer (for instance, equivalent potential temperature of $320 \mathrm{~K}$ above the Apennines in Fig. 16(b)). Another example over the Alps is shown in Fig. 12(d) (see small arrow) where the vertical velocity upstream from the first slopes is strong enough to allow a higher vertical extension, but the dry area located between $3500 \mathrm{~m}$ and $4500 \mathrm{~m}$ in height prevents convection developing more deeply. 


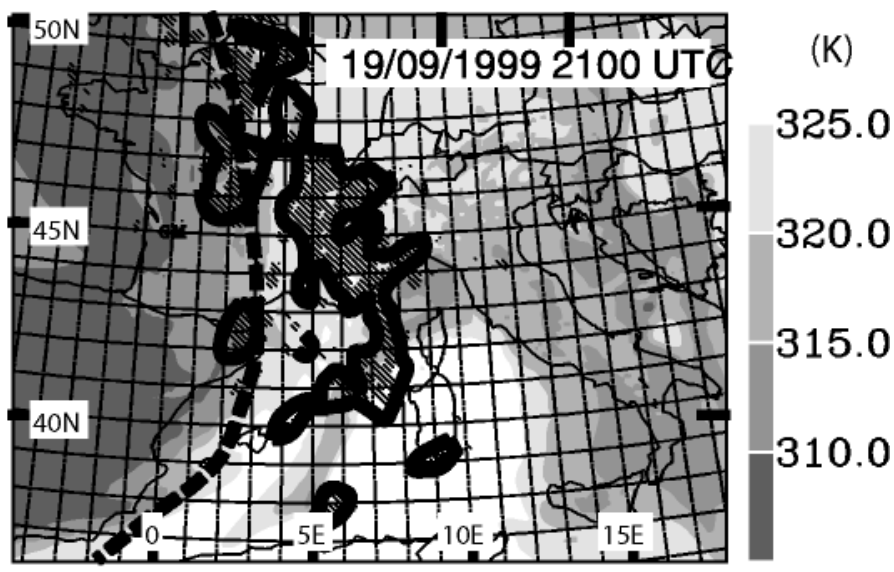

Figure 17. Equivalent potential temperature $(\mathrm{K})$ at $3000 \mathrm{~m}$ above sea level in grey scale (darkest areas associated with lowest values) and clouds at $8 \mathrm{~km}$ altitude (hatched areas inside thick isolines) from the $10 \mathrm{~km}$ model at 2100 UTC on 19 September 1999. The front is represented by the dashed line.

Moreover, Fig. 16(b) shows that a second cloud layer is present from $8 \mathrm{~km}$ up to the tropopause above the Alpine slopes. It corresponds to the upper-level clouds of the cold front. Its horizontal extension is shown in Fig. 17. The precipitation associated with these upper-level clouds contributes to the reduction of the middle-troposphere dry anomaly. At 2100 UTC on 19 September this cloudy layer arrives west of the Po Valley and the LMTA (see heavy isolines in Fig. 16(a)), yielding more favourable conditions for deeper clouds. This indeed corresponds to the most intense phase of the rainfall in the LMTA.

As a conclusion, two mechanisms are active during IOP 2b. (1) Convective cells are triggered over the Apennines and then either develop and move northwards over the Po Valley or dissipate. (2) The Alpine slopes in the LMTA initiate more intense convective cells when the barrier wind impinges on this terrain, and continually trigger supplementary cells over this area. The rainfall intensity over the LMTA is strongly controlled by two important features: the low-level easterly wind intensity and the presence of clouds (linked to the front) in the upper levels which humidify the middle-troposphere layer and provide more favourable conditions for deep convection to develop.

\section{CONCLUSION}

We studied the MAP IOP 2b (19-20 September 1999), which is a typical heavyprecipitation event in the Alpine region. A south-westerly to southerly flow drove moist air over the Mediterranean Sea towards the European mountains where convection was triggered. An active cold front crossed France and Italy during this IOP. A special emphasis was put on the LMTA in the concavity of the Alps because a lot of data were collected in this region by operational and research measurements. The precipitation maximum was found in this region (as in the climatology of autumn rain) and corresponded to persistent rain before, during and after the frontal passage. This maximum was less significant than the observations reported during extreme southerly Alpine cases but provided one of the most important accumulated rainfalls for the MAP field campaign. A numerical simulation of this IOP was performed with the non-hydrostatic model Meso-NH with a horizontal mesh of $2.5 \mathrm{~km}$. The results were 
successfully validated at different scales by comparison with the MAP measurements (http://www.map.ethz.ch/, October 2002).

The main conclusions of this case-study are summarized in the following statements:

- The $2.5 \mathrm{~km}$ mesh is sufficient to obtain a realistic simulation of the significant rain amounts for Alpine cases.

- The initial distribution of humidity in the low levels is particularly important in these situations, because the convective rain rate over the European mountains is modulated by upstream anomalies over the Mediterranean Sea. In our case, a large variation was found between two available analyses (ARPEGE and ECMWF).

- The conditionally unstable air masses over the sea associated with strong CIN and CAPE produce convective rainfall over the coastal mountains. The convective cells either move northwards over the Po Valley, possibly up to the Alps, or dissipate (first type of pre-frontal convection). Their vertical extension is limited by a mid-tropospheric dry layer.

- A second type of convection is present only over the Alpine slopes. Its forcing is provided by the barrier wind blowing in the north of the Po Valley and originating from the westwards deflection of a south-westerly to southerly synoptic flow. Though this wind is always present during the IOP, its origin changes greatly when the incident flow grows in amplitude with the eastwards progression of the jets ahead of the front. The rain rate over the LMTA is mainly controlled by the barrier wind intensity rather than the CAPE which remains almost constant and weak.

Although the clouds are modelled with a high level of quality, further work on this IOP is needed to validate the microphysics for the simulation of the cumulonimbus over the LMTA with the polarimetric radar S-Pol. Another line of work will be to study in more detail the moisture budgets over the different mountains around the Po Valley.

\section{ACKNOWLEDGEMENTS}

We acknowledge P. Bougeault for his comments about a preliminary version of the paper. Thanks are also due to G. Jaubert for her helpful discussions on the validation of the MAP IOP 2b simulations, F. Roux and J. F. Georgis for providing radar-derived wind fields and the MAP data centre for providing access to the data. Comments from two anonymous reviewers and H. Volkert helped us to significantly improve the paper.

Bechtold, P., Bazile, E., Mascart, P. 2001 and Richard, E.

Binder, P. and Schär, C. Eds.

Bougeault, P. and Lacarrère, $\mathrm{P}$.

1989

Bougeault, P., Binder, P., Buzzi, A., Dirks, R., Houze, R.,

Kuettner, J., Smith, R. B., Steinacker, R. and Volkert, $\mathrm{H}$.

Brandes, E. A., Vivekanandan, J.,

Tuttle, J. D. and

Kessinger, C. J.

Buzzi, A. and Foschini, L.

\section{REFERENCES}

A mass flux convection scheme for regional and global models. Q. J. R. Meteorol. Soc., 127, 869-886

1996 'MAP design proposal'. Available from MAP Programme Office, MeteoSwiss, CH-8044, Zürich, Switzerland, and URL: http://www.map.ethz.ch/proposal.htm

Parameterization of orography-induced turbulence in a meso-beta scale model. Mon. Weather Rev., 117, 1870-1888

2001 The MAP Special Observing Period. Bull. Am. Meteorol. Soc., 82, $433-462$

1995 A study of thunderstom microphysics with multiparameter radar and aircraft observations. Mon. Weather Rev., 123, 31293143

2000 Mesoscale meteorological features associated with heavy precipitation in the southern Alpine region. Meteorol. Atmos. Phys., 72, 131-146 
Buzzi, A., Tartaglione, N. and Malguzzi, P.

Chong, M., Georgis, J. F., Bousquet, O., Brodzik, S. R., Burghart, C., Cosma, S., Germann, U., Gouget, V., Houze Jr, R. A., James, C. N., Prieur, S., Rotunno, R., Roux, F., Vivekanandan, J. and Zeng, Z. X.

Cuxart, J., Bougeault, P. and Redelsperger, J.-L.

Frei, C. and Häller, E.

Frei, C. and Schär, C.

Gal-Chen, T. and Sommerville, R.

Georgis, J. F., Roux, F., Chong, M. and Pradier, $\mathrm{S}$.

Germann, U. and Joss, J.

Gheusi, F. and Stein, J.

Houze Jr, R. A. and Medina, S.

Jaubert, G. and Stein, J.

Lafore, J. P., Stein, J., Asencio, N., Bougeault, P., Ducrocq, V., Duron, J., Fischer, C., Héreil, P., Mascart, P. Redelsperger, J. L., Richard, E. and

Vilà-Guerau de Arellano, J.

Massacand, A. C., Wernli, H. and Davies, H. C.

Morcrette, J.-J.

Noilhan, J. and Planton, S.

Pierrehumbert, R. T. and Wyman, B.

Pinty, J.-P. and Jabouille, P.

Redelsperger, J. L., Parsons, D. and Guichard, F

Rotunno, R. and Ferretti, R.

Schneidereit, M. and Schär, C.

Sénési, S., Bougeault, P.,

Chéze, J. L., Cosentino, P. and Thepenier, R. M.
1998 Numerical simulations of the 1994 Piedmont flood: Role of orography and moist processes. Mon. Weather Rev., 126, 2369-2383

2000 Real-time wind synthesis from Doppler radar observations during the Mesoscale Alpine Programme. Bull. Am. Meteorol. Soc., 81, 2953-2962
2000

2001

1998

2003

2000

2002

2001

2003

1998
A turbulence scheme allowing for mesoscale and large-eddy simulations. Q. J. R. Meteorol. Soc., 126, 1-30

'Mesoscale precipitation analysis from MAP SOP rain-gauge data'. Pp. 257-260 in MAP Newsletter No. 15. MeteoSwiss $\mathrm{CH}-8044$, Zurich, Switzerland

A precipitation climatology of the Alps from high-resolution raingauge observations. Int. J. Climatol., 18, 873-900

On the use of a coordinate transformation for the solution of the Navier-Stokes equations. J. Comput. Phys., 17, 209-228

Triple-Doppler radar analysis of the heavy rain event observed in the Lago Maggiore region during MAP IOP 2b. Q. J.R. Meteorol. Soc., 129, 495-522

'Spatial Continuity of Alpine Precipitation'. P. 20 in proceedings of the MAP meeting 2000, 24-26 May 2000, Bohinjska Bistrica, Slovenia

Lagrangian description of air flows using Eulerian passive tracers. Q. J. R. Meteorol. Soc., 128, 337-360

Alpine precipitation mechanisms in MAP IOP $2 \mathrm{~b}$ and 8. Pp. 47-50 in MAP Newsletter No. 15. MeteoSwiss CH-8044, Zurich, Switzerland

Multiscale and unsteady aspects of a deep föhn event during MAP. Q. J. R. Meteorol. Soc., 129, 755-776

The Meso-NH atmospheric simulation system. Part I: Adiabatic formulation and control simulations. Annales Geophysica, 16, 90-109

Heavy precipitation on the Alpine south-side: An upper-level precursor. Geophys. Res. Lett., 25, 1435-1438

Radiation and cloud radiative properties in the European Centre for Medium-Range Weather Forecasts forecasting system. J. Geophys. Res., 96, 9121-9132

A simple parametrization of land surface processes for meteorological models. Mon. Weather Rev., 117, 536-549

Upstream effects of mesoscale mountains. J. Atmos. Sci., 42, 977-1003

'A mixed-phase cloud parametrization for use in mesoscale nonhydrostatic models: Simulations of a squall-line and of orographic precipitation'. Pp. 217-220 in proceedings of AMS conference on cloud physics, August 1999, Everett, WA, USA

Recovery processes and factors limiting cloud-top height following the arrival of a dry air intrusion observed during TOGACOARE. A three-dimensional simulation of a tropical squall line: Convective organization and thermodynamic vertical transport. J. Atmos. Sci., 59, 2438-2457

Mechanisms of intense Alpine rainfall. J. Atmos. Sci., 58, 17321749

Idealised numerical experiment of Alpine flow regimes and south-side precipitation events. Meteorol. Atmos. Phys., 72, 233-250

The Vaison-la-Romaine flash-flood: Mesoscale analysis and predictability issues. Weather and Forecasting, 11, 417-442 
Smith, R. B., Jiang, Q.,

Fearon, M. G., Tabary, P.,

Dorninger, M., Doyle, J. D. and Benoit, R.

Stein, J., Richard, E., Lafore, J. P. Pinty, J. P., Asencio, N. and Cosma, $\mathrm{S}$.

Thépaut, J. N., Alary, P., Caille, P., Cassé, V., Geleyn, J. F.,

Moll, P., Pailleux, J.,

Piriou, J. M., Puech, D. and Taillefer, $\mathrm{F}$.

Volkert, $\mathrm{H}$
2003 Orographic precipitation and airmass transformation: An Alpine example. Q. J. R. Meteorol. Soc., 129, 433-454

2000 High-resolution non-hydrostatic simulations of flash-flood episodes with grid-nesting and ice-phase parametrization. Meteorol. Atmos. Phys., 72, 203-221

1998 'The operational global data assimilation system at MétéoFrance'. Pp. 25-31 in proceedings of the HIRLAM 4 workshop on variational analysis in limited area models, Toulouse, France. HIRLAM 4 Project

2000 Heavy precipitation in the Alpine region (HERA). Meteorol. Atmos. Phys., 72, 73-85 